\title{
PENDAMPINGAN UMKM SAAT PANDEMI COVID-19 DENGAN TEKNOLOGI INFORMASI BERBASIS CMS WORDPRESS PADA ALPHONSE SHOE DI JAKARTA SELATAN
}

\author{
Tri Ika Jaya Kusumawati1), Teja Endra Eng Tju1) \\ 1)Program Studi Sistem Informasi, Fakultas Teknologi Informasi, Universitas Budi Luhur, Jakarta, Indonesia \\ Corresponding author : Tri Ika Jaya Kusumawati \\ E-mail : tri.ikajaya@budiluhur.ac.id
}

Diterima 30 Juli 2021, Direvisi 07 Agustus 2021, Disetujui 09 Agustus 2021

\begin{abstract}
ABSTRAK
Alphonse Shoe merupakan UMKM yang telah didampingi dalam kegiatan pengabdian masyarakat ini dengan tujuan agar dengan pemanfaatan teknologi informasi dapat berjualan secara daring dan bahkan berkembang lebih luas pemasarannya. Teknologi informasi berupa e-commerce berbasis CMS (Content Management System) WordPress. Di masa pendemi ini dengan alphonseshoe.com kegiatan pejualan sepatu tetap bisa dilakukan. Sebelumnya transaksi yang dilakukan belum optimal, media informasi berupa Instagram yang digunakan hanya untuk menampilkan barang-barang yang tersedia pada Alphonse Shoe sehingga pelanggan yang ingin membeli harus datang ke toko, dirasa masih kurang dalam memperbanyak tingkat penjualan barang. Metode pelaksanaan kegiatan terdiri dari tahap persiapan (observasi, wawancara, analisa), identifikasi dan pengolahan (desain, pengkodean, uji coba, implementasi), evaluasi (feedback, kuesioner), dan pembuatan laporan pengabdian masyarakat. Hasil dari pembuatan e-commerce telah dilakukan penilaian dengan kuesioner yang diperoleh hasil learnability $79,87 \%$, efficiency $78,21 \%$, memorability $83,10 \%$, error $83,73 \%$, satisfaction, $87,77 \%$, sehingga secara kesuluruhan nilai penerimaan user terhadap sistem e-commerce yang dibangun didapat nilai $82.54 \%$. Angka ini menunjukkan bahwa aplikasi atau sistem yang dibangun dapat diterima dengan baik dan berhasil memenuhi aspek usability system.
\end{abstract}

Kata kunci: content management; e-commerce; pandemi.

\begin{abstract}
Alphonse Shoe is an MSME that has been assisted in this community service activity with the aim that by using information technology it can sell online and even expand its marketing. Information technology in the form of e-commerce based on WordPress CMS (Content Management System). During this pandemic, with alphonseshoe.com, sales activities can be carried out. Previously the transactions were not optimal, the information media in the form of Instagram was used only to display the goods available on Alphonse Shoe so customers who wanted to buy had to come to the store, it was felt that they were still lacking in increasing the level of sales of goods. The method consists of the preparation stage (observation, interview, analysis), identification and processing (design, coding, testing, implementation), evaluation (feedback, questionnaire), and making paper reports. The results of the e-commerce creation have been assessed using a questionnaire. The results obtained are $79.87 \%$ learnability, $78.21 \%$ efficiency, $83.10 \%$ memorability, $83.73 \%$ error, satisfaction, $87.77 \%$, so that the overall acceptance value users of the built e-commerce system obtained a value of $82.54 \%$. This figure shows that the application or system that is built can be well received and successfully fulfills the usability aspect of the system.
\end{abstract}

Keywords: content management; e-commerce; pandemic.

\section{PENDAHULUAN}

Usaha Mikro, Kecil, dan Menengah atau UMKM terus berkembang. Menurut data BPS tahun 2017, unit UMKM (Usaha Mikro Kecil Menengah) menempati 99,9\% dari total unit usaha di indonesia dengan jumlah 62,9 juta unit usaha menurut bank indoneisa. Tidak hanya itu, UMKM menyerap 96,9\% terhadap produk domestik bruto (PDB) Indonesia (Gitiyarko, 2020).

Dalam situasi pandemi Covid-19 ini, UMKM yang bergerak dibidang fashion harus mengalami PPKM (Pemberlakuan Pembatasan Kegiatan masyarakat) karena bukan termasuk bidang yang esensial maka harus tutup atau pembatasan jam operasional (Bramasta, 2021). 
Salah satu UMKM dan terdampak aturan PPKM adalah Alphonse Shoe, yang dipilih sebagai mitra pengabdian masyarakat untuk di berikan pendampingan dengan pemanfaatan teknologi informasi agar dapat berjualan secara daring dan bahkan berkembang lebih luas penjualannya.

Aplikasi CMS pada umumnya bersifat open source seperti WordPress dan Blogger (Pratiwi et al., 2020). Karena bersifat open source sehingga tidak membutuhkan lisensi untuk penggunaan hal ini yang dipilih untuk dapat membantu UMKM rintisan (Marzuki et al., 2021). CMS Wordpress inilah yang diterapkan dalam kegiatan pengabdian kepada masyarakat ini (Feta et al., 2021).

\section{Kondisi Mitra}

Alphonse Shoe didirikan pada tahun 2018 oleh seorang pemuda yang bernama Putra yang awalnya mencoba berjualan sepatu baru maupun bekas. Dimulai dari diri sendiri yang melayani pelanggan, hingga saat ini mempunyai daua orang pegawai. Pada akhirnya, bisnis yang bermula dari ketidak sengajaan atau hanya mencoba tersebut mendapat untung yang menggiurkan dan melampaui ekspektasi dan kemudian mulai fokus menekuni bisnis tersebut. Lokasi toko berada di jalan Haji Muchtar Raya Gg. SDN 05 Pagi Petukangan Utara No. 03, RT 001/011, Jakarta Selatan, dengan kondisi tampak pada Gambar 1.

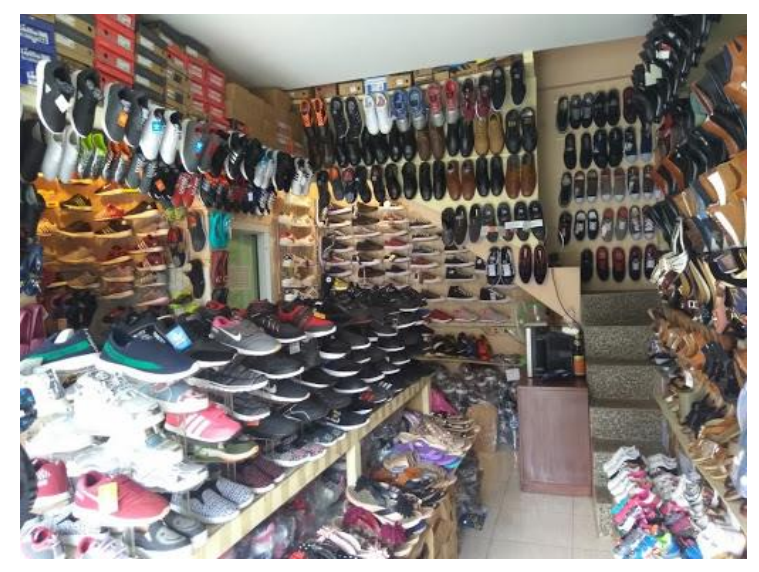

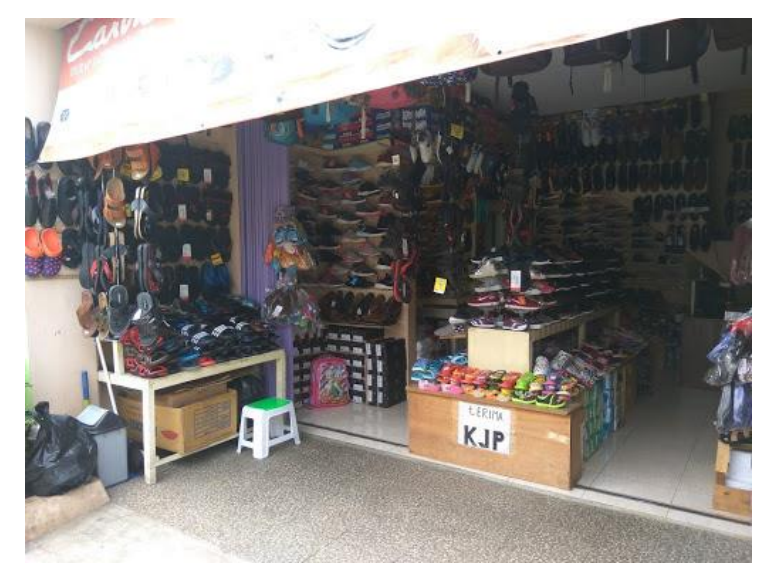

Gambar 1. Kondisi Toko Alphonse Shoe.

\section{Analisa Situasi}

Dalam menjalankan bisnis secara konvensional, Alphonse memiliki proses bisnis dalam melakukan berbagai kegiatan kerja yang sedang berjalan. Uraian proses bisnis secara garis besar:

a. Proses Pembelian Produk, pelanggan datang ke toko Alphonse dan dilayani oleh pagawai dalam hal menunjukkan, menjelaskan, memeriksa persediaan, dan mengemas produk.

b. Proses Pembayaran, dilakukan oleh pegawai dengan memberitahukan total harga kepada pembeli, menerima pembayaran, membuat tagihan yang sekaligus sebagai tanda terima, dan mencatat hasil penjualan.

c. Proses Laporan, setiap bulan pegawai merangkum data penjualan harian dalam bentuk spreadsheet dan menyerahkan kepada pemilik toko.

\section{Solusi untuk Mitra}

Di masa pandemi Covid-19, Alphonse Shoe sering tutup karena adanya peraturan PPKM untuk mencegah penyebaran virus, selain itu pengunjung toko sangat sedikit, karena mereka lebih memilih atau terpaksa harus tinggal dan bekerja di rumah. Suatu solusi yang bisa membantu yaitu membawa UMKM untuk beralih ke sektor digital (Khalifa, 2021).

Berdasarkan analisa situasi terhadap proses kegiatan yang sudah berjalan, solusi digital diberikan kepada Alphonse Shoe, berupa perbaikan dan penambahan proses yang diterapkan pada sistem e-commerce berbasis web dengan CMS (Content Management System) WordPress. Dengan menggunakan salah satu plugin terbaik untuk mendukung ecommerce yakni WooCommerce (Abdullah et al., 2021) Berikut proses-proses yang diusulkan:

a. Proses Pemesanan Produk, dilakukan melalui www.alphonseshoe.com. Berisi 
katalog produk yang dapat dipilih untuk melihat detail pemesanan, lalu pelanggan dapat mengisi variasi, jumlah pembelian, dan tambah ke keranjang belanja. Jika sudah sesuai dilakukan checkout menuju halaman detail pembayaran. Setelah mengisi data lengkap dan memilih kurir pengiriman, pilih proses order lalu secara otomatis admin dan pelanggan mendapatkan notifikasi pemesanan.

b. Proses Pembayaran, dilakukan dengan cara transfer ke rekening bank yang terdapat pada halaman Place Order. Pelanggan mengisi form pada halaman konfirmasi pembayaran yang telah dilakukan pelanggan. Lalu pegawai melakukan verifikasi data konfirmasi pembayaran, jika sesuai maka pegawai mengganti status Order menjadi status Processing Order pada halaman backend website dan notifikasi email ke pelanggan beserta Invoice, jika tidak sesuai maka email ke pelanggan bahwa pembayaran gagal.

c. Proses Pengiriman, ke alamat yang tertulis di Shipping Address yang telah diisi saat checkout. Pegawai mengganti status menjadi Order Complete dan pelanggan menerima email bahwa Order Complete beserta resi untuk pelanggan melakukan tracking.

d. Proses Pelaporan, dibuat laporan secara otomatis yaitu akumulasi berapa penjualan perbulan, produk terlaris, dan penerimaan pembayaran.

\section{METODE}

Pelaksanaan kegiatan pengabdian ini dilakukan dalam periode waktu Mei-Juli 2021, berlokasi di kampus Universitas Budi Luhur dan di lokasi Alphonse Shoe sebagai mitra. Perencanaan, analisa, perancangan, dan pembangunan system dilakukan di kampus, sedangkan implementasi dan pendampingan dilakukan di lokasi mitra. Gambar 2 menunjukkan peta lokasi kegiatan yang berjarak kurang lebih 1,3 km.

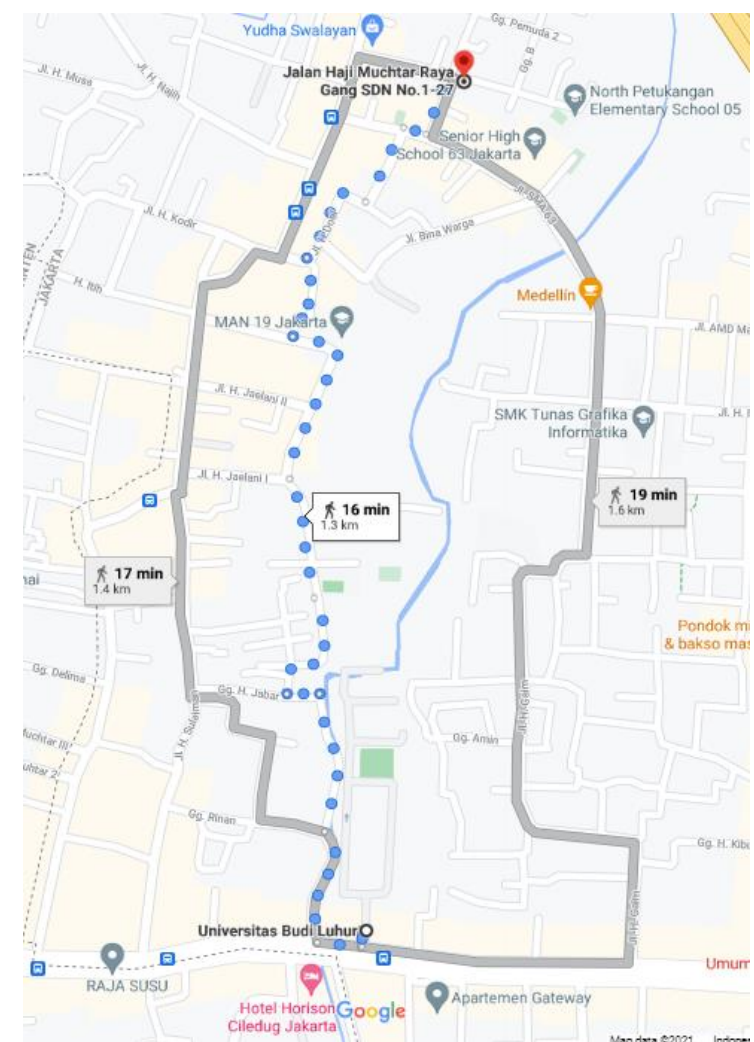

Gambar 2. Lokasi Kegiatan.

\section{Tahapan Pelaksanaan}

Berikut ini merupakan langkah-langkah pelaksanaan yang dilakukan dalam kegiatan ini (Gambar 3):

a. Tahap Persiapan, tahapan ini terdiri dari: Observasi di tempat mitra; Wawancara kepada mitra untuk menemukan masalah yang ingin diselesaikan; Analisa kebutuhan yang dilakukan setelah observasi dan wawancara untuk menentukan kebutuhan system.

b. Tahap Identifikasi dan Pengolahan, tahapan ini terdiri dari: Desain, tahapan perancangan sistem yang diusulkan; Pengkodean, tahapan pembuatan sistem sesuai desain; Uji coba sistem, tahapan pemeriksaan berjalannya sistem pada proses bisnis dan pelaporan; Implementasi, tahapan instalasi sistem untuk mitra.

c. Tahap evaluasi, merupakan tahapan feedback dari mitra pada hasil implementasi sistem dengan memberikan kuesioner kepuasan pengguna terhadap sistem yang dibangun.

d. Tahap pembuatan laporan, setelah semua tahapan disetujui maka dilakukan serah terima dan dilanjutkan pembuatan laporan dan publikasi kegiatan. 


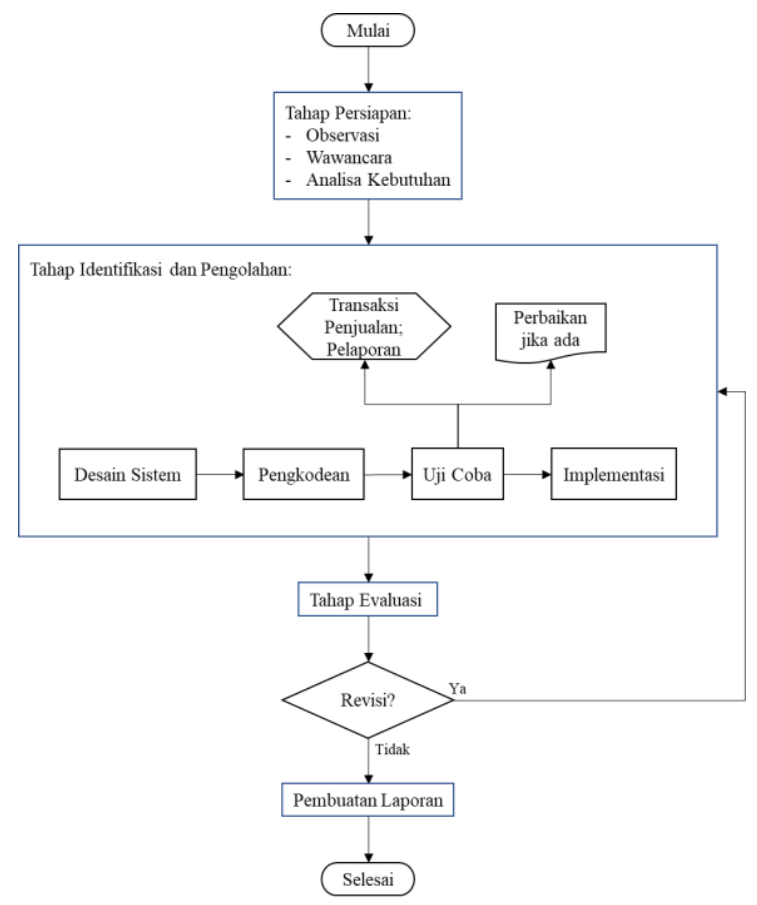

Gambar 3. Langkah Pelaksanaan.

\section{Sistem Deployment}

Spesifikasi komputer Alphonse Shoe yang digunakan untuk pembuatan sistem $e$ commerce berbasis web dengan CMS (Content Management System) WordPress dengan spesifikasi sebagai berikut:

a. Perangkat Keras

- Monitor: Samsung S20D300

- Mainboard: Intel

- Processor: Intel Core i3

- Hard Disk: Seagate 500 GB

- RAM: 4 GB DDR4

- VGA: Onboard

- Keyboard: Logitech Wireless

- Mouse: Logitech Wireless

b. Perangkat Lunak

- Operating System: Windows 7

- Office Applications: MS Office 2007 Indikator keberhasilan dari kegiatan ini adalah Alphonse Shoe tetap bisa melakukan proses penjualan dan pemasaran sehingga tetap eksis di masa pandemi dan semakin terkenal pada saat toko bisa beroperasional lagi.

\section{HASIL DAN PEMBAHASAN}

Situs e-commerce Alphonse Shoe telah dilakukan hosting dan dapat diakes pada https://alphonseshoe.com, seperti ditunjukkan pada Gambar 4. Secara komprehensif mencakup proses-proses pemesanan, pembayaran, pengiriman, dan pelaporan. Alphonse Shoe sangat terbantu dalam hal: memberikan informasi yang lebih cepat dan akurat bagi pembeli dan pegawai dalam hal harga, sediaan, rincian produk; sinkronnya pencatatan dalam transaksi penjualan dan persediaan yang ada di toko; minim terjadinya kesalahan harga dan perhitungan antara transaksi penjualan dan pembayaran; proses perhitungan dan pelaporan transaksi penjualan dapat dilakukan dengan waktu yang lebih cepat; serta memiliki situs e-commerce sehingga jangkauan pemasaran Istiana Sepatu lebih luas dan eksis.

Hal yang sangat disyukuri, dalam masa pandemik virus Covid-19, Alphonse Shoe bisa berjualan dengan e-commerce yang baru dibuat. Dengan adanya kebijakan PPKM dari pemerintah daerah yang berkelanjutan, menyebabkan toko fisik Alphonse Shoe sering tutup, selain itu pengunjung toko sangat sedikit, karena mereka lebih memilih tinggal di rumah, bekerja dari rumah, belajar dari rumah, berdoa dari rumah, dan belanja sepatu dari rumah juga.

Berdasarkan hasil yang telah dibuat untuk mitra, diajukan beberapa pertanyaan penilaian terhadap mitra menggunakan usability testing sederhana untuk hasil web ecommerce yang dibangun. Penilaian menyangkut:

a. Learnability, berdasarkan kemudahan penggunaan didapatkan nilai rata-rata $79,87 \%$.

b. Efficiency, berdasarkan kecepatan user dalam mengunakan sistem didapatkan nilai rata-rata $78,21 \%$

c. Memorability, berdasarkan ingatan user dalam langkah-langkah penggunaan sistem didapatkan nilai rata-rata $83,10 \%$.

d. Error, berdasarkan banyaknya user melakukan kesalahan dan memperbaikinya didapatkan nilai ratarata $83,73 \%$

e. Satisfaction, berdasarkan bagaimana perasaan user ketika mengunakan system yang ada didapatkan nilai ratarata $87,77 \%$

Secara kesuluruhan nilai penerimaan user terhadap sistem e-commerce yang dibangun didapat nilai $82.54 \%$. Angka ini menunjukkan bahwa aplikasi atau sistem yang dibangun dapat diterima dengan baik dan berhasil memenuhi aspek usability system. 


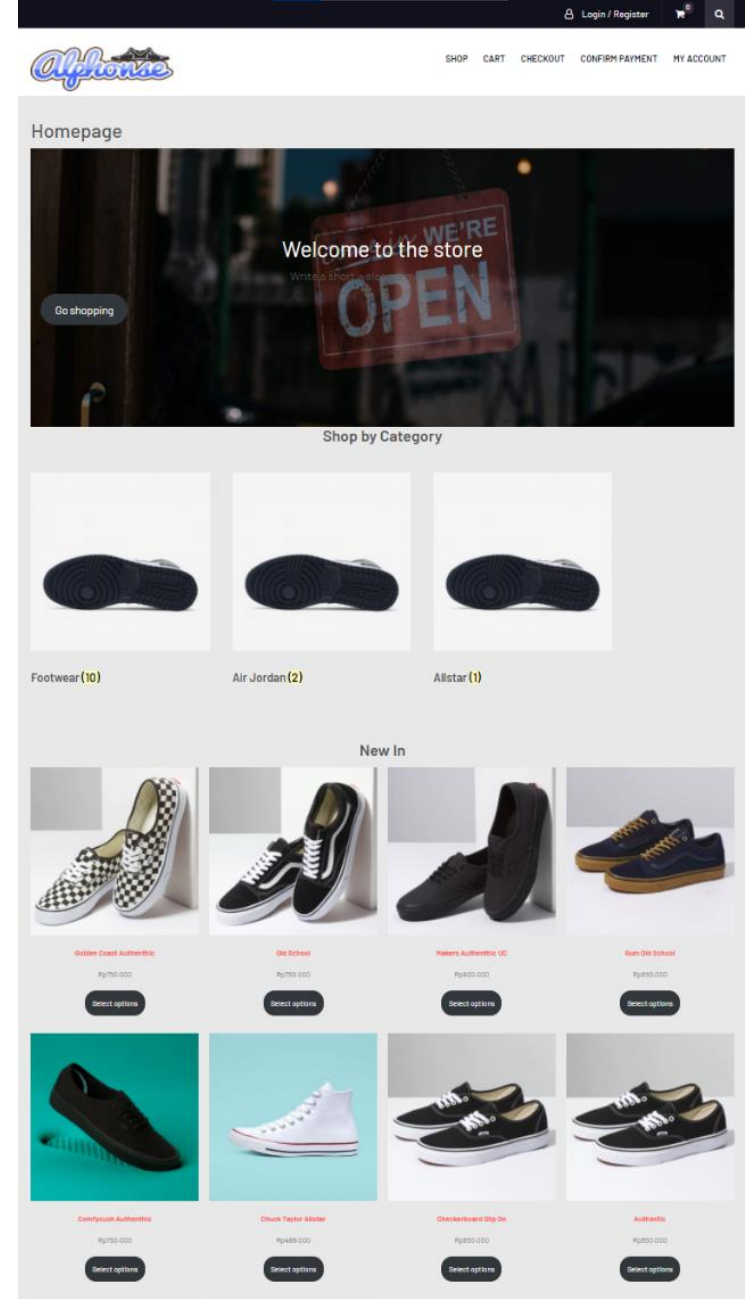

Gambar 4. Tampilan alphonseshoe.com.

\section{SIMPULAN DAN SARAN}

Berdasarkan hasil yang telah dibuat, dengan adanya website e-commerce, media promosi yang dilakukan menjadi lebih mudah diterapkan seperti informasi produk dan kupon potongan harga. Dengan adanya fitur laporan penjualan, pembayaran dan produk terlaris dalam website, maka proses laporan yang diberikan lebih cepat akurat. Fitur orders di dalam back-end website memudahkan pegawai mengelola pesanan.

Untuk melengkapi apa yang telah dilakukan dalam kegiatan ini, secara rutin operator harus melakukan back-up data, agar terhindar dari kehilangan data atau kerusakan. Pilihan pembayaran secara online dengan Kerjasama dengan payment gateway atau fintech. Juga ditambahkan pilihan kurir dan cara mendapatkan produk yang telah dibeli pelanggan.

\section{UCAPAN TERIMAKASIH}

Terimakasih kepada mitra Alphonse Shoe dan kepada Universitas Budi Luhur dan Yayasan pendidikan Budi Luhur Cakti yang telah memberikan dukungan dan tempat untuk berkarya.

\section{DAFTAR RUJUKAN}

Abdullah, A., Fauzan, A. G., \& Prasetyo, W. R. (2021). PELATIHAN PEMBUATAN WEBSITE E-COMMERCE DENGAN WOOCOMMERCE GUNA MENUMBUHKAN SEMANGAT TECHNOPRENEURSHIP PDA HMIF. JADIPAMAS (Jurnal Pengabdian Kepada Masyarakat), 5(1), 121-134.

Bramasta, D. B. (2021). Berlaku Hari Ini, Berikut Aturan Lengkap PPKM Darurat Jawa-Bali. Kompas.Com.

https://www.kompas.com/tren/read/2021/ 07/03/060300065/berlaku-hari-ini-berikutaturan-lengkap-ppkm-darurat-jawabali?page=all\#page2

Feta, R. N., Wiliani, N., \& Hesananda, R. (2021). Penggunaan dan pemanfaatan wordpress dalam upaya meningkatkan daya jual untuk pelaku umkm karang taruna bojongkulur. ABDIMAS Nusa Mandiri, 3(1), 1-3.

Gitiyarko, V. (2020). Kebijakan Perlindungan dan Pemulihan UMKM di Tengah pandemi Covid-19. Kompaspedia.Kompas.Id. https://kompaspedia.kompas.id/baca/pap aran-topik/kebijakan-perlindungan-danpemulihan-umkm-di-tengah-pandemicovid-19

Khalifa, R. lira. (2021). Pengembangan UMKM Digital di Masa Pandemi Covid-19. Kompasiana.Com.

https://www.kompasiana.com/lyrareinekh alifa8629/60cc3b959f7b9d6758659742/p engembangan-umkm-digital-di-masapandemi-covid19 ?page $=1$ \&page_images $=1$

Marzuki, K., Apriani, A., \& Dasriani, N. G. A. (2021). Pemberdayaan Pengrajin Perak Melalui Market Place sebagai Media Penjualan Online di Desa Ungga,Kabupaten Lombok Tengah. ADMA : Jurnal Pengabdian Dan Pemberdayaan Masyarakat, 1(2), 107114. https://doi.org/10.30812/adma.v1i2.1023

Pratiwi, D., Santoso, G. B., Mardianto, I., Sediyono, A., \& Rochman, A. (2020). Pengelolaan Konten Web Menggunakan Wordpress, Canva dan Photoshop untuk Guru-Guru Wilayah Jakarta Web Content Management Using Wordpress, Canva and Photoshop for Teachers of the Jakarta Region. Jurnal IImiah Pengabdian Pada Masyarakat, 2(1), 12. 